\title{
CHANGES IN THE ADVERTISING INDUSTRY IN THE CONTEXT OF THE GLOBAL LOCKDOWN-2020: ECONOMIC AND SOCIAL ISSUES
}

${ }^{\circ 2020}$ BUCHNA YU. A., DAVYDOV D. S.

UDC 659.1:005.1-048.76]:614.46(100)

JEL: M31; M37

Buchna Yu. A., Davydov D. S. Changes in the Advertising Industry in the Context of the Global Lockdown-2020: Economic and Social Issues

The article is aimed at highlighting major changes in advertising and marketing at the international level as a result of the coronavirus pandemic and the resulted global economic crisis. When carrying out a detailed analysis of scientific articles, the main trends were identified, according to which the modern advertising industry in the world will continue to change, and a vision of possible ways to further develop the situation in the context of the international crisis in the economy has been formed. The key indicators of the economic crisis have been defined and their impact on the decisions of advertising agencies on the choice of means, channels and content of advertising campaigns is highlighted. A new direction has been formed in which advertising agencies implement and promote their own campaigns. The relevance of on-line advertising during the lockdown period is substantiated, namely, advertising on social networks, video resources and streaming platforms; advertising embedded in online games, etc. Benefits of broadcasting advertising through on-line channels compared to traditional advertising methods are allocated and substantiated. Prospect of this direction of research is to determine the most effective methods and topics of on-line advertising in order to reach a new audience and increase the customer base of advertising agencies. For in today's world information technology occupies the position of the most actual way to move business forward in any sphere, a significant share of investments are made in new ad formats, payment models and technology solutions that meet or surpass global industry standards. Further development of the sphere of digital advertising can lead to even more displacement of the off-line methods of advertising from the market: because the end consumers no longer use a PC in order to go on-line, but more often browse the Internet resources from their portable devices.

Keywords: advertising campaign, on-line advertising, advertising agency, world crisis.

DOI: $h$ ttps://doi.org/10.32983/2222-4459-2020-10-413-419

Fig.: 3. Bibl.: 8.

Buchna Yuliia A. - Graduate Student of the Department of Management and Administration, Educational and Research Institute "Karazin Business School» of V. N. Karazin Kharkiv National University (1 Myronosytska Str., Kharkiv, 61002, Ukraine)

E-mail: buchnaia@gmail.com

Davydov Denys S. - PhD (Economics), Associate Professor, Director of the Karazin Center for Entrepreneurship, Educational and Research Institute «Karazin Business School» of V. N. Karazin Kharkiv National University (1 Myronosytska Str., Kharkiv, 61002, Ukraine)

E-mail:d.davydov@karazin.ua

ORCID: http://orcid.org/0000-0002-8323-1597

УДК 659.1:005.1-048.76]:614.46(100)

JEL: M31; M37

Бучна Ю. А., Давидов Д. С. Зміни в рекламній індустрії в умовах глобального карантину 2020: економічні та сочіальні засади

Метою статті є висвітлення ключових змін у галузі реклами та маркетингу на міжнародному рівні внаслідок пандемії коронавірусу та спричиненої ним глобальної економічної кризи. Проводячи детальний аналіз наукових статей, було визначено основні тендениії, за якими надалі буде зазнавати змін сучасна рекламна індустрія у світі, та сформовано бачення можливих шляхів подальшого розвитку ситуації в рамках міжнаціональної кризи в економіці. Визначено ключові показники економічної кризи та висвітлено їх вплив на рішення рекламних агентств щодо вибору засобів, каналів та змісту рекламних кампаній. Сформовано новий напрям, у якому рекламні агентства втілюють та просувають свої кампанії. Обгрунтовано актуальність проведення в період карантину онлайн-реклами, а саме, реклами в соціальних мережах, на відеоресурсах і на стримінгових платформах; реклами, вбудованої в онлайн-ігри, тощо. Виділено та обгрунтовано переваги трансляції реклами завдяки онлайн-каналам порівняно з використанням традиційних методів проведення реклами. Перспективою цього напряму дослідження є встановлення найбільш ефективних методів та тем онлайн-реклами з метою охоплення нової аудиторії та збільшення клієнтської бази рекламних агентств. Оскільки в сучасному світі інформаційні технології займають позиції найактуальнішого способу просувати вперед бізнес у будь-якій сфері, значна частка інвестицій відбувається в нові формати оголошень, моделі оплати та технологічні рішення, які відповідають світовим галузевим стандартам або перевершують їх. Подальший розвиток сфери диджитал-реклами може привести до ще більшого витіснення офлайн-методів проведення реклами з ринку: адже кінцевий споживач більше не використовує тільки ПК для того, щоб вийти в Інтернет, а частіше переглядає Інтернет-ресурси зі своїх портативних пристроїв.

Ключові слова: рекламна кампанія, онлайн-реклама, рекламне агентство, світова криза.

Рис.: 3. Бібл.: 8. 
Бучна Юлія Андріївна - магістрантка кафедри управління та адміністрування, Навчально-науковий інститут «Каразінська школа бізнесу» Харківського національного університету імені В. Н. Каразіна (вул. Мироносицька, 1, Харків, 61002, Україна) E-mail: buchnaia@gmail.com

Давидов Денис Станіславович - кандидат економічних наук, доцент, директор Каразінського центру підприємництва, Навчальнонауковий інститут «Каразінська школа бізнесу» Харківського національного університету імені В. Н. Каразіна (вул. Мироносицька, 1 , Харків, 61002, Україна)

E-mail: d.davydov@karazin.ua

ORCID: http://orcid.org/0000-0002-8323-1597

$\circlearrowleft$ tarting from January 2020, the COVID-19 pandemic has brought some serious challenges to the processes of stabilizing the global economy amidst the lockdown. Thus, all the world industries are changing their dynamics. The COVID-19 pandemic has largely influenced the way brands, advertising agencies, and multiple other businesses function, thus disrupting the constantly developing advertising and marketing industries. All the leading economies of the globe have faced a severe recession in their revenue as the businesses are shut [4]. All these circumstances make it essential for advertisers to reconsider their entire approach in order to create a connection with the correct target audience. As people spend the maximum of their time staying at home during the COVID-19 quarantine, connecting with them through digital media has become more convenient than ever. For these purposes, advertisers need to have a set of actions aimed at attracting investors and keeping their audiences engaged in the content, e. g., by using the right media platforms.

Economic Prerequisites. The advertising industry has a rule of thumb that states that expenditure on advertising should follow any rise or fall in GDP. Over recent years, as global GDP has risen on average by $4 \%$ each year, the advertising cluster has also grown, reaching about 646 billion USD. in 2019 [3], meaning that before the Coronavirus pandemic, the advertising market was forecast to increase to 865 billion USD by 2024. However, now there is a deviation to the principle that businesses decrease advertising budgets due to the economic downturn. Advertising agencies have already been through some economic tensions, political pressures, and even ecological disasters, but most of these difficulties are short-lived. Whereas the global outbreak of COVID-19 is bringing newer and newer challenges that agencies must cope with, widespread travel restrictions have been stated all over the planet. Most developed countries are under total lockdown. Governments of many countries across the globe have emerged as advertising purchasers to promote public health ideas or support journalism.

The advertising businesses are inseparable from the media business model. Except for public service media, financed by taxes, the entire media ecosystem is dependent on advertising revenues [7]. The COVID-19 crisis has very strongly impacted the advertising system. This crisis is predicted to bring some long-term changes and new tendencies into the advertising industry. Companies are making survival their priority now, but in the future, they will have to discover unique ways of brand building. The shift in media channels usually used by people as well as overall consumption habits will force a reconsideration of how best to bring them to life.

Coronavirus Lockdown Impact. All the nononline ad types like outdoor, print, or cinema media have found these times extremely challenging, as the areas of display advertising have felt the impact of cut budgets. Under pandemic circumstances, brands appeared under the pressure of decreasing revenue and tried to conserve their expenditure and find out how and where to connect with their consumers. When confinement measures were set around the world, outdoor and cinema advertising shrank almost immediately; the volume of print advertising also shrank. At the same time, in-home media popularity went up. The number of television advertising has increased; however, digital consumption has risen even more: the usage of social media platforms and streaming services has grown almost in every country; gaming has also increased rapidly.

$\mathrm{F}$ ocusing on in-home advertising, more and more ad agencies are working out ways to promote online and conduct meetings in digital format to deal with this unprecedented crisis. This tendency has top media agencies all over the world hold corporate or internal meetings over Skype, Zoom, WebEx, or other services. Ad agencies are encouraging their employees to work from home at least until the virus-infected tendency starts to fall. 
One can notice an increase in the audiences because people start having more free time right with the start of the global lockdown (Fig. 1). Also, the level of competition fell dramatically because many advertising agencies are terminating their campaigns. People are becoming more engaged, but they are beginning to convert less. Consequently, audiences require different messaging for advertising campaigns. That is why digital news publishers are particularly influenced by the current situation. Brands are avoiding associations with coronavirusrelated ad content and are withdrawing money and blocking keywords across programmatic channels of news websites and platforms. lockdown [4]. Additionally, advertising agencies depend heavily on interpersonal connections and the physical presence of their personnel at the office. This is the reason many of them are rethinking the internal processes during self-isolation times.

$\mathrm{T}$ he drop in advertising revenue due to the COVID-19 pandemic starts from 50\% for television and radio advertising and goes to 99\% for billboard ads during the confinement. As per the analysis of the IntoTheMinds online-platform of the impact of the pandemic on the media industry, the annual decrease in advertising campaign revenues is estimated at $10 \%$ for television and

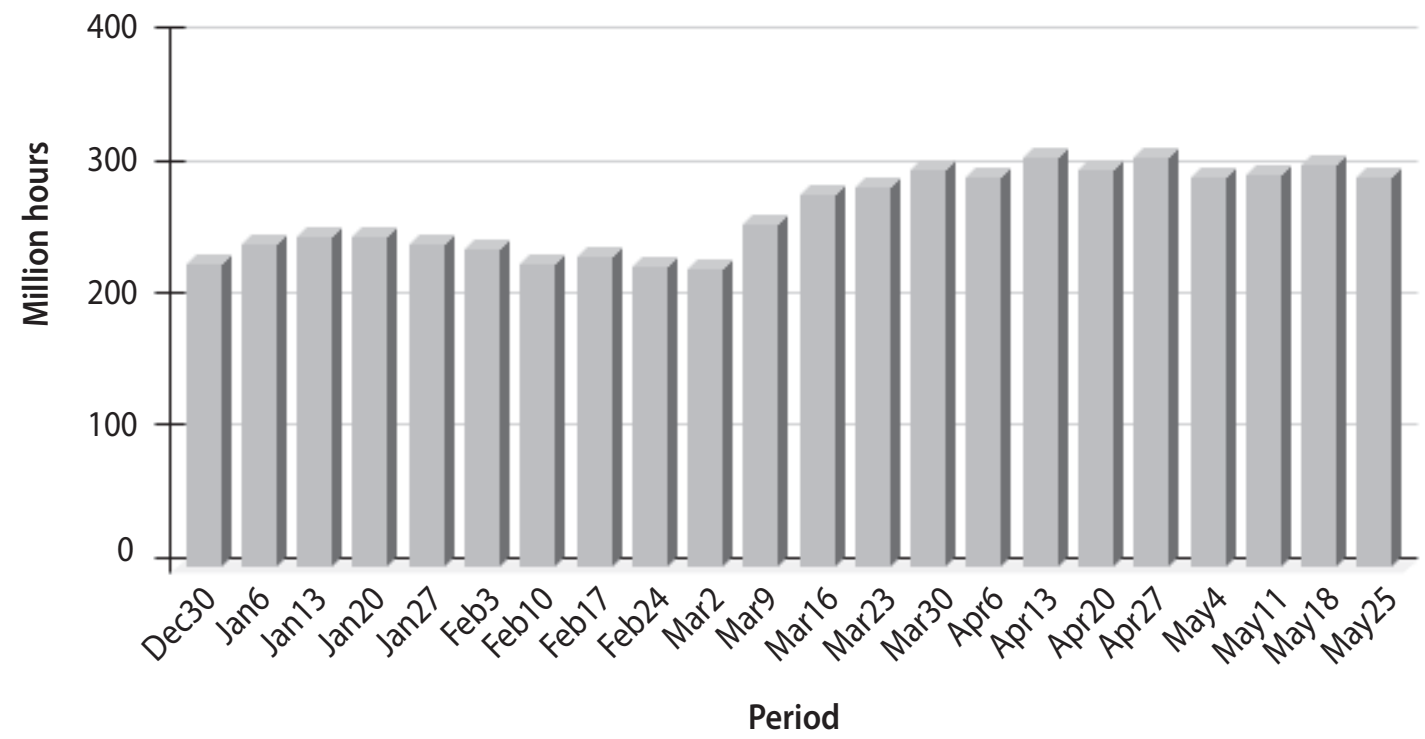

Fig. 1. The average number of hours spent online by week

Source: Interactive Advertising Bureau (IAB) [1].

S ince consumer behavior has shifted, advertising expenditure has adjusted in response. Naturally, it makes no sense for ad agencies to spend money on media that have no audience. Spending on advertising has now made a large shift from the traditional ways of advertising, namely newspaper advertisements, hoardings, printed brochures, etc., to online web-platforms. These include such widely known social platforms as YouTube, Instagram, Netflix, Spotify, Facebook, Snapchat, etc. Global advertising campaigns are expected to sink in the nearest future as the lockdown has led to a break in travel tourism as well as the entertainment industry, which both have affected the overall demand. These changes in the global ad spending are especially well-traced in the way brands have chosen to spend, particularly on platforms used as a means to increase their sales during and after the radio and over $25 \%$ for out of home display (Fig. 2) [7]. However, it is worth noticing that these values should not be considered low if compared to the data for the beginning of the 2010s.

Changes in Advertising. In terms of the global crisis, advertisers should carefully watch consumer's preferences and adjust to them as accurately as never before, which means prioritizing online advertising. The digital environment is favorable for the so-called direct-response-campaigns. They are encouraging immediate purchases by consumers by offering them an appealing bargain. For brands, this is made for cautious spending and looking to drive sales. This means that top digital advertising creators tend to cope with the coronavirus negative consequences. In China, for example, where consumers spend two-thirds of their media time online, the income of the top advertising agencies in the first quarter increased by $32 \%$ [3]. 


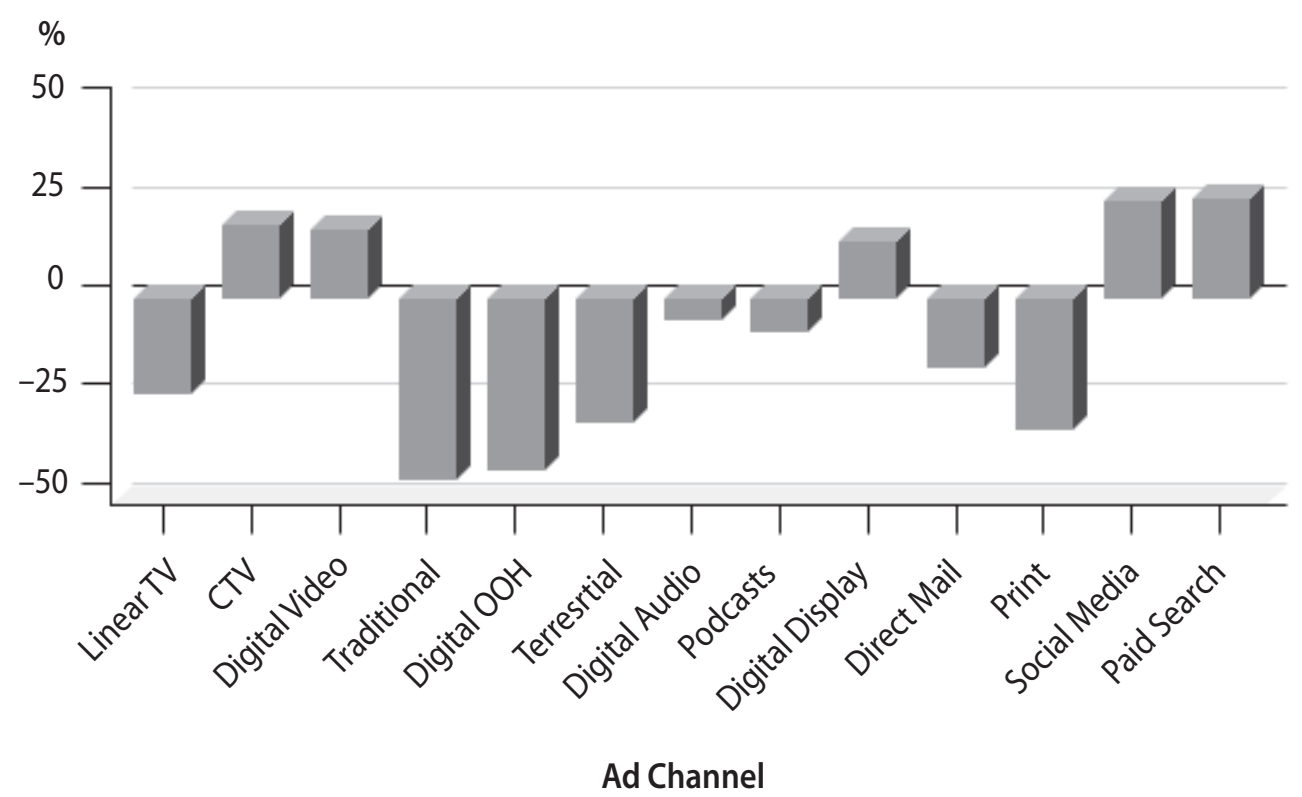

Fig. 2. Changes in 2020 spendings vs 2019

Source: Interactive Advertising Bureau (IAB) [1].

A dvertising messages are now being fixed by market experts to fit the current situation. The coronavirus opened debates concerning omitting sharp news, making it difficult for news publishers to monetize big audience attention. However, encouragingly, some confidence starts to get back to the advertising industry, as companies adapt and lay their way through the COVID-19 environment. Steady growth in sponsorship and revenue amount can be noticed in some sectors of the advertising industry, with mobile advertising and CTV (Connected TV) outperforming other platforms [5].

In-game advertising revenue has also grown at a great scale since the beginning of quarantine, as consumers spend more time on mobile and PC games, and any platform that receives monetization by increasing app downloads as opposed to ad revenue has influenced this process particularly well.

Brand security and mobile analytics specialists have also experienced high demand for their technology as brands try to protect themselves and to encompass the effectiveness of the advertising expenditure, making sensitivity in the advertising highly important. This has initiated increased pressure on traditional publishers. Their offer flow is increasing sharply, "yet monetizing this is challenging against the backdrop of decreased budgets and (some) overly-aggressive brand safety measures", Mobile Marketing Magazine states [5].

Similar to in-game mobile advertising, influencer marketing on social media platforms have experienced audience and revenue engagement. As consumers are spending more time engaging socially, advertisers have followed their example.

The sweepstakes and contest areas have been seriously affected by COVID-19 because brands do not want to seem isolated or tone-deaf to the consequences of the pandemic. Notwithstanding the risks involved, sweepstakes, contests, and giveaways provide brands with an opportunity to engage consumers during an uncertain time [2].

$\mathrm{F}$ or instance, brands practice awarding consumers with gift cards to restaurants and retailers or awarding grocery gift cards to the front-line medical workers. This practice helps brands increase customer conciliation and loyalty. Having that said, nowadays brands should keep in mind the required conformity with all applicable federal, state, and local laws that apply to promotional instruments. These law requirements usually include compliance with lottery laws, preparing official rules as well as right disclosures concerning the prize offered, odds, and entry methods [2]. All the rules, including the free entry requirements or requirements for alternative methods of entries, can be very complicated and may vary by promotion type.

COVID-19 has forced many advertising companies and other businesses to close or provide a limited range of services to their customers. Trying to overcome the loss of revenue, agencies made selling gift cards to consumers their priority both for 
current and future use. This encourages purchasing once businesses go back to normal pace while the pandemic continues to disrupt business as usual [2]. Gift cards give brands the possibility to sustain the income flow with costless goods sold in an unfortunately slow time for business.

Challenges in Advertising during the Pandemic. One of the key reasons why expenditure on advertisement has been decreasing lately is because of the attitudinal change in consumer behavior. Most of the advertising agencies will experience negative consequences on their business as advertising revenues are shrinking rapidly. Even though sales processes are somewhat stopped because of the pandemic, what is worth noticing is the way brands continue advertising. They proceed with creating awareness through digital channels by posting TVCs and appearing on Instagram pages, showing the way brands are planning to be with their audience even during these rough times. Almost all the leading agencies have processed different means and ways to stay afloat by creating a special connection with their audiences on popular issues like lockdown, quarantine, self-isolation by playing around strategically with these terms [4]. For example, agencies are modifying their logos to promote keeping social distancing; also, supermarkets and stores have even started safely delivering groceries or goods by following safety guidelines of leaving delivery at doorsteps to hold their consumers' credibility.

The cancellation of conducting live sports games and events has been a challenge for television networks and media agencies like The Atlantic and The Athletic, even leading some of them to fire their staff while others started switching to holding virtual events [2]. Another field in business that cannot be taken online is production work. For instance, the Association of Advertising Producers (ASAP) representing 75 producer members, that does approximately $90 \%$ of the advertising work in India has decided to hit the pause button [6]. Along with other film production companies, it has unanimously made a decision to stop all shoots beginning from March to the end of the pandemic. Besides, clients have ceased answering to approvals raised by production agencies and companies.

Ad Agencies Status. By analyzing the way the sphere works with brands, technology vendors, agencies, and publishers, and by talking to most of the customers throughout this spring, a clear picture of the effect that COVID-19 has on the advertising ecosystem can be seen [5]. The whole ecosystem of advertising has been placed under pressure and is looking forward to economic stabilization. The latter phenomenon will create a steady base for the future revival of the advertising industry.

$\mathrm{D}$ ue to the information that agencies provided for the research of the IntoTheMinds platform, the overwhelming majority of advertising companies have shifted their ad campaigns around while waiting for a clearer picture of the current economic situation. It is also obvious that from this perspective, brands are incredibly cautious when it comes to communication (Fig. 3). In comparison with the minimum confidence index over the last 50 years, Fig, 3 shows that nowadays its value is far from the levels reached in 2008. The move of advertising campaigns has resulted in commitments that were made to the media industry at the beginning of this year. Intensive negotiations are at the moment underway to process all the necessary contracts with clients. The agencies strive for customer's attention and client demand, but not for revenue from projects anymore [7]. The issue still needs more monitoring and expert advice regarding the question of proper management of the current situation.

$75 \%$ of the advertising agencies asked ceased their investments in advertising in April 2020 [7]. On the contrary, $25 \%$ of them took advantage of the COVID-19 pandemic situation to raise their funds, primarily in quite significant proportions. Apart from the governmental advertisements or any other official advertisements made by the authorities, the level sometimes increases to $250 \%$. "The brands that have overinvested during the confinement are active in traditional retail (except for low-cost retail), home furnishings, internet, and mobile access", states IntoTheMinds platform [7]. An outstanding exception here is Coca-Cola, which has completely terminated its investments in self-advertising.

The top advertising agencies are already recovering from temporary unemployment, thus their savings plans have been revealed to publicity. Publicis, for instance, announced a massive savings plan of 500 million euros. This plan is expected to result in total pausing of hiring processes, as well as a reduction in the use of freelance force and applying restrictions on taking holidays during crisis times. Redundancies are, of course, not the subject to fear, however, they could be extremely harmful in terms of market recovery. Indeed, in case of any sudden market breakdown, there is a probability that those who have left the market cannot be immediately 


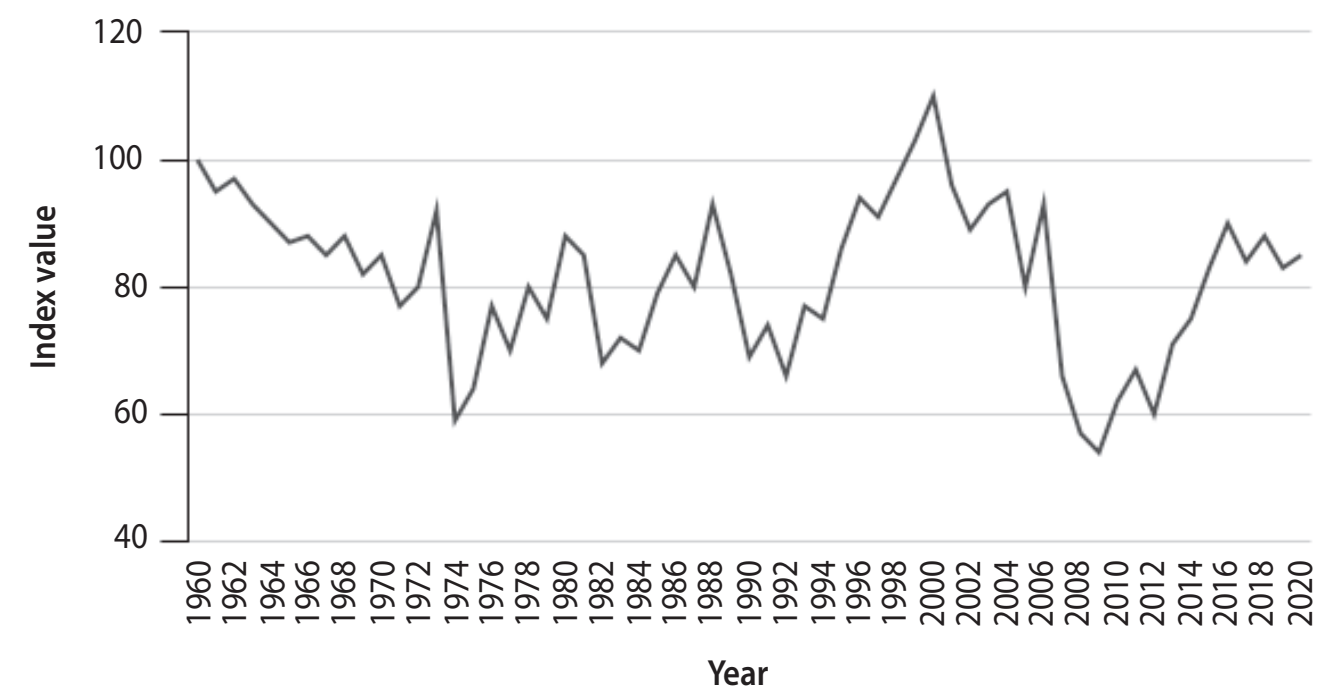

Fig. 3. Change of consumer confidence index over the last $\mathbf{5 0}$ years

Source: IntoTheMinds online-platform [7].

reintegrated [7]. This practice is especially risky for people involved in the creative industry.

All in all, leading the advertising business during hard pandemic times is a real challenge. For some companies, it may be better to choose to shift their focus on other marketing efforts. For others, the time needed to adjust the message and goals of their advertising campaigns matters. As all the tasks they do continuously tend to seem flawless, crisis times are also a good chance to see if business advertisements are properly built to track audiences and have better data [8]. What one needs here, is to determine what is going to bring the most profit and value.

\section{CONCLUSIONS}

As a result of the COVID-19 lockdown, the majority of advertising agencies and companies have ceased their advertising investments almost simultaneously. While some of the advertising campaigns were simply postponed, the others were stopped completely. Agencies experienced an extremely sharp revenue decrease, which led to campaign cost-cutting measures. It is expected, that unless deconfinement happens, brands can only reinvest in advertising campaigns during holiday times.

The advertising companies with accurately developed analytics will definitely have an obvious advantage over the other agencies in the advertising industry. Many advertising companies, the overwhelming majority of which rely on it for income generation, are prioritizing direct response marketing in ad campaigns. Though ad expenditure is gradually reducing, spending on online platform advertising has reduced more slowly. Speaking from the longer-term perspective, this may strengthen the position of digital platforms in the following two ways. Firstly, they seem to suffer less comparing to other ad companies in the advertising ecosystem, which gives them an opportunity to emerge at a higher pace and become stronger after the crisis. Secondly, these agencies own behavioral data collected during the pandemic. These data are extremely important in an industry where everyone is trying to percept consumer habits, so this will give platforms a competitive advantage over the others.

The changes in consumer behavior that have arisen from the economic crisis result in a review of all advertising content and messages brands had for their campaigns before the pandemic hit. Consumer expectations are also shifting towards the need for reinsurance, refocusing on essential aspects of life such as home and family. On top of that, the in-depth workarounds stimulated by crisis help restore deeper meaning and values to nowadays advertising.

\section{LITERATURE}

1. COVID Ad Spend Impact 2020 \& 2021: Light at the End of the Tunnel. URL: https://www.iab.com/insights/covid-ad-spend-impact-2020-2021-light-atthe-end-of-the-tunnel/

2. DiResta A., Williford K., Cohen D., Genn B. The Impact of COVID-19 on Your Advertising and Marketing Campaigns. URL: https://www.hklaw.com/ en/insights/publications/2020/04/the-impact-ofcovid19-on-your-advertising-and-marketing-campaigns 
3. Li C., Hall S. This is how COVID-19 is affecting the advertising industry. URL: https://www.weforum.org/ agenda/2020/06/coronavirus-advertising-marketing-covid19-pandemic-business/

4. Makani S. COVID-19's impact on global ad spending and its fallout on the Indian advertising industry. URL: https://bestmediainfo.com/2020/06/COVID19-s-impact-on-global-ad-spending-and-its-fallout-on-indian-advertising-industry/

5. Murphy D. COVID-19s impact on the advertising industry. URL: https://mobilemarketingmagazine. com/COVID-19s-impact-on-the-advertising-industry

6. Nair P., Vardhan H. Coronavirus impact: How the Indian ad industry is dealing with uncertainty. URL: https://brandequity.economictimes.indiatimes. com/news/industry/COVID-19-impact-how-theindian-ad-industry-is-dealing-with-uncertainty/74682372

7. Schwab P. COVID-19: 9 specific impacts on the advertising industry and its future. URL: https://www. intotheminds.com/blog/en/covid-impact-advertising-industry/

8. The Impact of COVID-19 on the Digital Advertising Industry. URL: https://www.vendasta.com/blog/ the-impact-of-COVID-19-on-the-digital-advertising-industry/

\section{REFERENCES}

"COVID Ad Spend Impact 2020 \& 2021: Light at the End of the Tunnel". https://www.iab.com/insights/covid-ad-spend-impact-2020-2021-light-at-the-endof-the-tunnel/
DiResta, A. et al. "The Impact of COVID-19 on Your Advertising and Marketing Campaigns". https://www. hklaw.com/en/insights/publications/2020/04/theimpact-of-covid19-on-your-advertising-and-marketing-campaigns

$\mathrm{Li}, \mathrm{C}$., and Hall, S. "This is how COVID-19 is affecting the advertising industry". https://www.weforum.org/ agenda/2020/06/coronavirus-advertising-marketing-covid19-pandemic-business/

Makani, S. "Covid-19's impact on global ad spending and its fallout on the Indian advertising industry". https://bestmediainfo.com/2020/06/covid-19-simpact-on-global-ad-spending-and-its-fallout-onindian-advertising-industry/

Murphy, D. "COVID-19s impact on the advertising industry". https://mobilemarketingmagazine.com/ covid-19s-impact-on-the-advertising-industry

Nair, P., and Vardhan, H. "Coronavirus impact: How the Indian ad industry is dealing with uncertainty". https://brandequity.economictimes.indiatimes. com/news/industry/covid-19-impact-how-theindian-ad-industry-is-dealing-with-uncertainty/74682372

Schwab, P. "COVID-19: 9 specific impacts on the advertising industry and its future". https://www.intotheminds.com/blog/en/covid-impact-advertisingindustry/

"The Impact of COVID-19 on the Digital Advertising Industry". https://www.vendasta.com/blog/theimpact-of-covid-19-on-the-digital-advertising-industry/ 